\title{
The Attitude of The Persons who are Dealing with Disabled People with Different Disabilities Towards Integrating the Disabled with Ordinary People
}

\section{DR.Walaa Labib Mohamed El Desoki}

Assistant Professor at Education and Psychology

Department, Faculty of Science and Arts, AL - Qurayat

AL - Jouf University, Saudi Arabia \& Faculty Member

at Faculty of Arts, Menoufia University, Egypt

\section{Abstract :}

7 he present study aims at identifying the attitude of dealing with disabled people with different disabilities towards integrating the disabled with ordinary people. The sample of the study consisted of 200 individuals dealing with people with different disabilities by 196 females and 4 males. The attitude towards integration scale was also used. The results indicated that there were no significant differences among the handicapped in the direction of integration according to the gender variable, while there were significant differences among the handicapped with the handicapped in the direction towards the integration according to the place of residence in favor of the big cities compared to the middle cities, and the benefit of the middle cities compared to the villages. There were also significant differences among the handicapped in the direction of integration according to the job variable for the benefit of the handicapped. There are significant differences among the handicapped in the direction of integration according to the variable of the presence of a disabled child in the family in favor of the people who have a handicapped in their families, and also found significant differences in the dealers. With the disabled in the trend towards integration according to the type of disability variable according to the table attached to the research.

Key words : Attitude - Disabled People - Integrating

\section{Introduction :}

- There has been an attitude in the past years that calls for the integration of people with special needs, especially in education systems, This attitude 
reverses the attitude of isolation that has been followed previously with people with special needs. In addition to developing its capabilities and developing its preparations for effective participation in society.

- The process of integrating the disabled in Menoufia governorate is based on a weak infrastructure. In addition to the limited financial capabilities within schools and educational institutions that do not allow the construction of classes and the provision of equipment, standards and tools for integration, there is also a high degree of non-activation of the results of the studies reached In the field of integration in addition to the lack of full awareness, on the part of those involved in the educational process , of the importance of educational integration

- One of the main challenges that African countries are facing in this regard is the shortage of qualified teachers with the requisite skills to provide an appropriate education for their children with special needs. This shortage can be addressed through provision of professional development to all inservice teachers in the area of special and inclusive education. (Chitiyo, , et al ,2019)

- Professional development of teachers is important in order to maintain a high standard of student learning. (Chitiyo, , et al ,2019). We emphasize on the significance of "education for all", integration is the approach that best suits the purposes of special education. (Rodriguez, \& Garro, ., 2015)

\section{Theoretical Framework:}

- It is a fact that worldwide, handicapped students have difficulties in continuing their education. These difficulties cause the handicapped people to suspend 
or end their education. This creates a negative point of view among handicapped students towards education and decreases the participation of handicapped people in education. However, previous studies . ( Karal ; et al , 2011)

- In Egypt like Russia, problem of the study of integrative resources of the personality of children and teenagers with disabilities is being actualized. It has been done in order

- To improve psychological and pedagogical support which promotes the process of

- their socialization and successful integration into society. ( Konovalova , 2016 ).

- Many specialists in the field of special education criticized the attitude of isolation, which is based on the isolation of people with special needs away from their ordinary peers in the educational environment, which entails social isolation, so many workers in the field of special education at the present time advocate integrating children with special needs with their ordinary peers In the educational system, which entails breaking the psychological barrier between the two parties in addition to providing the opportunity for people with special needs to develop their educational, social and psychological abilities ( Al-Jabbar, 1998) .

- However, the concept of integration requires a great effort from the family and those in charge of the educational process and the disabled, especially with the negative effects of integration such as ostracism, neglect or denial of learning opportunities by ordinary peers (Kellett, 2007 ) 


\section{Integration Forms:}

- Spatial integration: refers to the placement of persons with disabilities in special classes attached to ordinary schools

- functional integration : refers to the participation of the disabled with ordinary students in the use of available materials

- 3-Social integration : refers to the participation of the disabled with ordinary students in non-academic activities such as play, trips and art education. (AlRousan, 2001 ) .The success of the integration process depends on the teachers' attitude towards integration . ( Saratawi ,1995).

- Integration needs to identify the categories to be integrated in addition to teacher preparation and rehabilitation, and modification of study programs, and the preparation of classes and psychological preparation for parents and the disabled. Attitude : according to Allport's definition, it is a state of neurological and mental preparedness that is regulated by experience and has a direct influence on individual behavior towards all subjects and situations. (El Desouki, 2010).

- Direction Components: Direction consists of three basic components : The cognitive component, the emotional component, the behavioral component .

- The attitude to teaching students with special needs in general education classrooms initiated in the 1980s due to the attempts of parents who demanded equal educational opportunities for their children (O’Dell \& Schaefer, 2005). Many scholars supported inclusive education and highlighted the value of 
integration of each student in a school without considering whether they have any disability and making them a part of the school culture (Cansiz; Cansiz. , 2018)

Combs, Elliott, \& Whipple (2010) \& Khudorenko (2011) said that the Special needs students are deprived of suitable education when they are taught at a mismatched level with students who are significantly above their level. This can negatively affect a student's sense of self-esteem and dignity. Even in physical education classes, students with physical disabilities are disadvantaged because the

curriculum is not gear to include them. This can cause students with special needs to face discrimination and bullying from their peers, this has caused them to experience low self-esteem, isolation, depression, and in some cases aggression. These emotional breakdowns can lead to violence . (Khudorenko , 2011)

While it is easy for some special needs students to handle adjustment strategies, it is difficult for others. Adjustment need is one in which every individual serves as a source of emotional support, companionship, social and economic support of other people within and outside their environment. Among the special students, total acceptance of their significance to others, parental support, visitation to them at school by significant others, engaging them with opportunities (job, craftwork etc) are necessary for these students to adjust with their condition at least as long as theaffliction insist (Balogun, 2004).and (Omotosho, 2019)

Underlying reason for choosing one approach over the others (school system, a segregated or an integrated 
classroom ) is a philosophical one, having to do with what it means to be human belonging in a civilized society (Dixon S., 2005)

The integration of the disabled and the good students became one of the most important recent attitudes in special education. Integration is service provided to students with disabilities within the study program so that the school consisting of joint classes of good and disabled students replaces schools for disabled. (Selema, F., 2017)

Aksoy; and Bercin (2008) observed that the healthy children's attitudes towards their handicapped sibling are clearly changing according to diagnosis and level of handicap whereas the same factors do not make any difference in terms of attitudes towards other handicapped people .

The evidence from the study of suggested that, in the Turkish context, grade level and training for inclusive education did not make a significant contribution to increase PTs' sentiments, and attitudes, and to lessen their concerns about inclusion . (Cansiz, M.; Cansiz, N. , 2018)

Çelik (2008) has found that the empathic tendency levels of female teachers working in the field of special education are higher than the empathic tendency levels of male teachers and this condition has been interpreted in the way that this can be related to the maternal instinct and being understanding towards individuals .

( Esentas, M. et al ,2019) indicated that the curriculum for the disabled can be stated to be an important process in changing the perspectives of the participants towards the disabled positively. they has been concluded that the professional anxiety and expectations of the Department of 
Exercise and Sports Education for the Disabled - which will also ensure the socialization and integration of the disabled individuals.

( Any way ) Disabled people have rights and duties like all members of the community and they need to be included and adapted. (Ziadat, A. H.; Atiyat, F.A. , 2018)

\section{The Problem of the Study :}

- Are there any statistically significant differences in the attitude towards integration among the handicapped by gender?

- Are there any statistically significant differences in the attitude towards integration among the handicapped according to the place of residence?

- Are there any statistically significant differences in the attitude towards integration between the dealers with the handicapped according to the social and cultural level?

- Are there any statistically significant differences in the attitude towards integration among those dealing with the handicapped according to the situation of children in the family?

- Are there any statistically significant differences in the attitude towards integration among the handicapped according to the type of disability?

\section{Objective of the Study :}

The present study aims to determine the attitudes of workers with disabilities towards the process of integration in the governorate of Menoufia, and does this attitude differ according to the type of disability that is being dealt with, and whether it varies according to the type of the person dealing with the disabled person, his place of 
residence, whether rural or urban, his culture and the presence of a disabled child in his family.

So we must use a life-care planning guide in a medical history of the person with a disability and a record of desires and/or the desires of his or her parents concerning the type of care the disabled child should receive. (Ehrenberg,.2017) .

\section{The Importance of the Study :}

- Theoretical importance: In general, there are many benefits of integration, such as improving the interaction of the handicapped student and the development of social and academic capabilities and the establishment of psychological links between him and his peers and reduce his sense of loneliness rather than his sense of loneliness and isolation. The importance of the current study is to determine the extent of knowledge of the Menoufia community for the integration of the disabled, the advantages and disadvantages of the integration process, and the attitudes of the members of the Menoufia community working with the handicapped towards the integration process, and to know what kind of integration is most useful from the point of view of the study population

- Applied importance: It is represented in the use of the results of the officials in the governorate of Menoufia in the attempt to apply the process of integration within the schools of the governorate of Menoufia, as well as guidance towards conducting courses for teachers and staff and students to help them accept and help their peers with disabilities 


\section{The Population of the Study :}

The study population consists of Teachers and employees who deal with students of special needs, They consists of ( 196 female and 4 males ) who deal with children with special needs in schools of intellectual education and handicapped , Alnour schools, and Alamal schools for handicapped students in the governorate of Menoufia .

\section{The Sample of the Study :}

The sample of the study consisted of 200 teachers and employees( 196 female and 4 males ) who deal with children with special needs in schools of intellectual education and handicapped , Alnour schools, and Alamal schools for handicapped students in the governorate of Menoufia from the following cities (Shebin El Kom, Quesna, Menouf, Ashmoun, Berket El-Sabea, Tala, Elshohadaa, Sers Layyan, Sadat, Bagour)

\section{Terminology of the Study :}

\section{Special Needs :}

children with special needs are exceptional children that need special education to be able to learn at their own rate and to develop to their maximum capacity without special education . (Adegboyega ,. 2019).

They are individuals in the community who have special needs that are different from those of other members of the society. These needs are represented in programs, services or equipment. The nature of these needs determines the characteristics of each individual with special needs, including those with special needs (disabled, gifted), We are Interested in the current study category of disabled 


\section{handicap :}

A significant delay in sensory or physical development, psychological or mental, resulting in special difficulties and needs. (Ibrahim, 2008).

The most important types of disabilities are:

- Mental disability.

- Blindness and/or Vision Impairment.

- Deaf or Hearing loss .

- Physical disabilities.

- Learning disabilities ..(Tavarez., 2019 ).

- Students who have great difficulty organizing their thoughts and putting them into words are not motivated to write ( Courduff, ,2011).

- Autism

- Behavioral disorders

- Delinquents with anti-social behavior

- Speech and language disorders. (Al-Khatib \& AlHadidi , 2014).

\section{The Second term ( Integration ) :}

It is intended to provide equal opportunities for learning for handicapped students by attaching them to an educational environment capable of meeting their needs, thus providing opportunities for academic and social interaction. (Fouad \& Ibrahim, 2007).(

\section{The third term : Attitudes towards integration :}

There are three main attitudes towards integration :

A) The first attitude: opposes the idea of integration and considerd the education of people with special needs in their own schools more effective

B) The second attitude: support the idea of integration because of its good impact on modifying the attitudes of the Egyptian society towards people with special needs. 
The third attitude: supports that the integration of people with simple or moderate disabilities with ordinary people should not be integrated with those with severe disabilities. (Omaira, 2001).

This Third term dealing with people with special needs: means those dealing with the disabled, both teachers and staff in schools with special needs.

In reviewing the previous studies we find that there are three types of results: The first category of studies confirmed the presence of more positive trends towards integration, including the study of (Center,. \& Curry, 1993, and Alkashef , 1999) who confirmed that the integrated students were better in language communication skills and social skills and grades compared to isolated students In addition, Freeman et al, (2000) assert that those who are integrated are better at measures of academic achievement and social competence, Shash,( 2001) noted that mentally retarded people learned by simulating motor and verbal simulation by imitating the behavior of ordinary children. Rafferty, et al , (2003) also emphasized that receptive, expressive and social language skills were better for the integrators, while behavioral problems increased for non-integrators . Abdelhamid, (2003) pointed out that the integration of the mentally retarded with the normal led to the development of motor, linguistic, mental, cognitive and social development and increased the degree of adaptation of the mentally retarded, Qaryouti (20090 and Hakim (2009) also agree that teachers who worked with people with special needs have more positive attitudes Compared to teachers who don't work with them. Receptivity, expressionism and social skills were better among the integrated, while behavioral problems increased among the non-integrated. Al-Sayegh,( 2011) pointed out that teachers who worked with people with special needs had 
more positive attitudes than teachers who did not work with them. The second category of studies confirmed negative attitudes towards integration, such as the study of Dupoux et al,(2005,) which found that $80 \%$ of teachers in a Haytee school in the United States of America have negative attitudes towards integration, Kaffemanas. ( 2007) indicated that $75 \%$ of teachers and students have negative attitudes. Al shakhes, (1986) found that the tendency of education workers (principals, agents, teachers, social workers and psychologists) towards the disabled was more sympathetic to the visually impaired compared to the mentally retarded. Al-Khashrami , (2011) noted that many disabled people face difficulties in conducting their social and educational affairs.

While the third category of studies indicated that there are no statistically significant differences between the integrated and non integrated on both social efficiency and social interaction such as the study of Hardiman \& Fitzsimon (2008), and the study of Abdul Jabbar \& Masoud,(2002) which pointed to the divergence of the sample of the study which consisted of 447 managers and teachers Employees in integration schools towards integration by disability category and program type.

The studies of Hegazy (2012), Zeeb and Maheidat, (2013) recommended the need for a level of autonomy, communication skills, interaction, communication, selfreliance and targeted behavior for autistic students by integrating them with ordinary people.

\section{Study Hypothesis :}

- There are no statistically significant differences in the attitude towards integration among persons with disabilities according to gender 
- There are no statistically significant differences in the atittude towards integration among the handicapped according to the place of residence.

- There are no statistically significant differences in the attitude towards integration among the handicapped according to social and cultural level.

- There are no statistically significant differences in the attitude towards integration among those dealing with the disabled according to the situation of children in the family.

- There are no statistically significant differences in the attitude towards integration among the handicapped according to the type of disability.

\section{Study Methodology and Procedures :}

The researcher used the descriptive method

\section{Study Tools :}

- Identifying persons with disabilities according to the diagnosis of the institution to which they belong.

- The attitude towards integration scale : After researching the previous studies, researches, websites and scientific articles, the researcher designed a scale consisting of 30 phrases that measure the attitude towards integration and revolve around three axes (cognitive, skillful, and sentimental), and the statements of the scale are answered by choosing (very agree, agree, neutral, disagree, not agree at all) and the degree ranges on each statement 1:5, and the degree on the scale as a whole ranges from 30 degrees: 150 degrees

\section{First : Facial Validity :}

The researcher verified the validity of the measure by presenting it to (8) university professors specialized in 
Special needs and psychology in The Arab Republic of Egypt) .

\section{Second : The Validity of the Internal Structure :}

The validity of the internal structure of the scale was verified by applying the scale to (30) persons from outside the sample and within the community, to determine the correlation between the paragraphs and the total score, the correlation coefficients ranged between $(0.65-0.73)$ and was a function at the level $(0.05)$ which indicates The relationship between the degree of the paragraph and the total score of the scale.

\section{Third : correlating validity :}

The current scale was applied to a sample of (30) persons and another scale in integration was also applied at the same sample. The correlation coefficient between the two scales was 0.87 , which indicates an appropriate positive correlation

\section{Reliability :}

Reliability in the way of re-scale : Reliability was calculated by repetition by applying the scale to the standardization sample of (30) students from the study population and from outside the study sample and then reapplied after two weeks of the first application, The testretest coefficient of moral intelligence was 0.88 , a high coefficient

Reliability was extracted by Alfa Kronbach scale $=0.93$ Scale Correction::

The scale consists of 30 phrases that measure the attitude towards integration and revolve around three axes (cognitive, skillful, and sentimental), and the statements of the scale are answered by choosing (very agree, agree, 
neutral, disagree, not agree at all) and the degree ranges on each statement 1:5, and the degree on the scale as a whole ranges from 30 degrees: 150 degrees

\section{Method of application:}

The researcher distributed the attitude towards integration scale to the study sample . The study sample consisted of 200 teachers and employee who deal with special needs and staff in schools of intellectual education, Alnour schools for handicapped, and Alamal schools for handicapped in the El Menoufia Governorate from the following cities (Shebin el Kom, Quesna, Menouf, Ashmoun) by 196 women and 4 men (teachers and psychological employees

\section{The statistical methods :}

The researcher calculated the percentages and iterations and used Excel, SPSS to express the statistics in the tables in a realistic way that reflects the percentage of the respondents of the sample in question on each item of the questionnaire and then on each axis of the study. The (t).test was used to indicate the differences in the study sample. The single variance analysis test was used to indicate the differences in the study sample responses. The LSD test was performed to determine the attitude differences.

\section{Results :}

\section{1)The First Hypothesis :}

There are no statistically significant differences in the attitude towards integration among persons with disabilities according to gender.

To verify this hypothesis, the t-test was used to denote differences in study sample responses to the mean scale by gender 
Table (1) $t$ - test for the significance of differences in the responses of the study sample to the meanD at the significance at level (.05)

\begin{tabular}{|c|c|c|c|c|c|c|c|}
\hline & \multicolumn{2}{|c|}{ Male } & \multicolumn{2}{|c|}{ Female } & \multirow{2}{*}{$\begin{array}{l}\text { The } \\
\text { value } \\
\text { of } T \text {. }\end{array}$} & \multirow{2}{*}{$\begin{array}{l}\text { Significance } \\
\text { level }\end{array}$} & \multirow[b]{2}{*}{ Significance } \\
\hline & SMA & $\begin{array}{l}\text { standard } \\
\text { deviation }\end{array}$ & SMA & $\begin{array}{l}\text { standard } \\
\text { deviation }\end{array}$ & & & \\
\hline $\begin{array}{l}\text { Integration } \\
\text { scale }\end{array}$ & 3.79 & .608 & 3.38 & .786 & 1.121 & .88 & Is a function \\
\hline
\end{tabular}

From the previous table it is clear that that There are no statistically significant differences in the attitude towards integration among persons with disabilities according to gender

\section{2) The Second Hypothesis :}

There are no statistically significant differences in the atittude towards integration among the handicapped according to the place of residence .

To verify this hypothesis, a single variance analysis test was used to detemine The significance of differences in the responses of the study sample to the integration scale according to the place of residence

Table (2) The significance of differences in the responses of the study sample to the integration scale according to the place of residence(Single

\begin{tabular}{|c|c|c|c|c|c|c|c|}
\hline \multicolumn{8}{|c|}{ variance analysis test) } \\
\hline The hub & $\begin{array}{l}\text { Contrast } \\
\text { Source }\end{array}$ & $\begin{array}{l}\text { Total } \\
\text { squares }\end{array}$ & \begin{tabular}{|l|} 
Degrees \\
of \\
freedom
\end{tabular} & $\begin{array}{l}\text { Average } \\
\text { of } \\
\text { squares }\end{array}$ & $\begin{array}{l}\text { The } \\
\text { value } \\
\text { of } \mathbf{F}\end{array}$ & $\begin{array}{l}\text { Significance } \\
\text { level }\end{array}$ & Significance \\
\hline \multirow{3}{*}{ Integration } & \begin{tabular}{|l|} 
Between \\
groups
\end{tabular} & 48.488 & 2 & 24.244 & \multirow{3}{*}{89.689} & \multirow{3}{*}{$\cdots$} & \multirow{3}{*}{ Function } \\
\hline & $\begin{array}{l}\text { Within } \\
\text { grouns }\end{array}$ & 53.252 & 197 & \multirow{2}{*}{270} & & & \\
\hline & Total & 101.74 & 199 & & & & \\
\hline
\end{tabular}

$\mathrm{D}$ at the significance level 0.05$)($

From the previous table it is clear that there are statistically significant differences in the attitude towards integration between the dealers with the disabled according to the place of residence. 
To determine the direction of the differences, the LSD test was performed

Table ( 3 ) The LSD test

\begin{tabular}{|l|l|l|l|l|}
\hline The hub & $\begin{array}{l}\text { Type of } \\
\text { comparative } \\
\text { housing }\end{array}$ & $\begin{array}{l}\text { Accommodation } \\
\text { type }\end{array}$ & $\begin{array}{l}\text { Differences } \\
\text { between } \\
\text { averages }\end{array}$ & Significance \\
\hline Integration & $\begin{array}{l}\text { Small town } \\
\text { Big city }\end{array}$ & Village & $\begin{array}{l}\mathbf{0 . 7 3 -} \\
\text { 0.36- }\end{array}$ & $* . .$. \\
\cline { 2 - 5 } & Big city & Small town & $\mathbf{1 . 0 9 -}$ & $* . \cdots$ \\
\hline
\end{tabular}

There are statistically significant differences in favor of the type of housing (small city) and (big city) when compared to the type of housing (village) at the level of significance (0.000) and (0.001) respectively

There are statistically significant differences in favor of the type of housing (big city) when compared to the type of housing (small city) at the level of significance (0.000) .

\section{3) The Third Hypothesis :}

There are no statistically significant differences in the attitude towards integration among the handicapped according to social and cultural level.

To validate that hypothesis we used Single variance analysis test to determine the significance of the differences in the responses of the study sample to the integration scale according to the social and cultural level.

Table ( 4 ) Single variance analysis test

\begin{tabular}{|c|c|c|c|c|c|c|c|}
\hline The hub & $\begin{array}{l}\text { Contrast } \\
\text { Source }\end{array}$ & $\begin{array}{l}\text { Total } \\
\text { squares }\end{array}$ & $\begin{array}{l}\text { Degrees } \\
\text { of } \\
\text { freedom }\end{array}$ & $\begin{array}{l}\text { Average } \\
\text { of } \\
\text { squares }\end{array}$ & \begin{tabular}{|l} 
The \\
value \\
of $F$
\end{tabular} & $\begin{array}{l}\text { Significance } \\
\text { level }\end{array}$ & Significance \\
\hline \multirow{3}{*}{ Integration } & \begin{tabular}{|l|} 
Between \\
groups
\end{tabular} & 15.495 & $r$ & 7.747 & \multirow{3}{*}{17.696} & \multirow{3}{*}{$\cdots$} & \multirow{3}{*}{ Function } \\
\hline & \begin{tabular}{|l|} 
Within \\
groups
\end{tabular} & 86.246 & 198 & \multirow[t]{2}{*}{.438} & & & \\
\hline & Total & 101.740 & 199 & & & & \\
\hline
\end{tabular}

$D$ at the significance level 0.05 ) 
JREIET

Table ( 5 ) the LSD test

\begin{tabular}{|l|l|l|l|l|}
\hline The hub & the level & $\begin{array}{l}\text { Comparative } \\
\text { level }\end{array}$ & $\begin{array}{l}\text { Differences } \\
\text { between } \\
\text { averages }\end{array}$ & Significance \\
\hline Integration & Low & $\begin{array}{l}\text { Medium } \\
\text { High }\end{array}$ & $\begin{array}{l}1.08- \\
0 .-34\end{array}$ & $* . \cdots$ \\
& Medium & High & $\mathbf{0 . 7 3 -}$ & $\ddots \cdots 1 *$ \\
\cline { 2 - 5 } & Medium & $\ddots \cdots$ \\
\hline
\end{tabular}

From the previous table, it is clear that there are statistically significant differences in the attitude towards integration between the dealers with the disabled according to social and cultural level.

To determine the direction of the differences, the LSD test was performed

There are statistically significant differences in favor of the level (medium) when compared to the level (low) at the level of significance $(0.000)$.

There are statistically significant differences in favor of the level (high) when compared to the level (medium) at the level of significance (0.001).

\begin{tabular}{|c|c|c|c|c|c|c|c|}
\hline The hub & $\begin{array}{l}\text { Contrast } \\
\text { Source }\end{array}$ & $\begin{array}{l}\text { Total } \\
\text { squares }\end{array}$ & $\begin{array}{l}\text { Degrees } \\
\text { of } \\
\text { freedom }\end{array}$ & \begin{tabular}{|l|} 
Average \\
of \\
squares
\end{tabular} & $\begin{array}{l}\text { The } \\
\text { value } \\
\text { of } F\end{array}$ & $\begin{array}{l}\text { Significance } \\
\text { level }\end{array}$ & Significance \\
\hline \multirow{3}{*}{ Integration } & \begin{tabular}{|l|} 
Between \\
groups
\end{tabular} & 7.946 & 2 & 3.973 & \multirow{3}{*}{8.344} & \multirow{3}{*}{$\cdots$} & \multirow{3}{*}{ Function } \\
\hline & $\begin{array}{l}\text { Within } \\
\text { groups }\end{array}$ & 93.794 & 197 & \multirow{2}{*}{.476} & & & \\
\hline & Total & 101.740 & 199 & & & & \\
\hline
\end{tabular}

$D$ at the significance level 0.05

\section{4) The Forth Hypothesis :}

There are no statistically significant differences in the attitude towards integration among those dealing with the disabled according to the situation of children in the family 
To verify this hypothesis, a single variance analysis test was used to determine the significance of differences in the responses of the study sample to the integration scale according to the situation of children in the family

Table ( 7 ) Single variance analysis test

\begin{tabular}{|l|l|l|l|l|l|l|l|}
\hline The hub & $\begin{array}{l}\text { Contrast } \\
\text { Source }\end{array}$ & $\begin{array}{l}\text { Total } \\
\text { squares }\end{array}$ & $\begin{array}{l}\text { Degrees } \\
\text { of } \\
\text { freedom }\end{array}$ & $\begin{array}{l}\text { Average } \\
\text { of } \\
\text { squares }\end{array}$ & $\begin{array}{l}\text { The } \\
\text { value } \\
\text { of F }\end{array}$ & $\begin{array}{l}\text { Significance } \\
\text { level }\end{array}$ & Significance \\
\hline \multirow{5}{*}{ Integration } & $\begin{array}{l}\text { Between } \\
\text { groups }\end{array}$ & 7.946 & 2 & 3.973 & & & \\
\cline { 2 - 5 } & $\begin{array}{l}\text { Within } \\
\text { groups }\end{array}$ & 93.794 & 197 & \multirow{2}{*}{8.344} & $\ldots$. & Function \\
\cline { 2 - 5 } & Total & 101.740 & 199 & .476 & & & \\
\hline
\end{tabular}

$D$ at the significance level 0.05

From the previous table, it is clear that there are statistically significant differences in the attitude towards integration between the dealers with the disabled according to the situation of children in the family.

To determine the direction of the differences, the LSD test was performed

Table ( 8 ) the LSD test

\begin{tabular}{|c|c|c|c|c|}
\hline The Hup & Status & $\begin{array}{c}\text { Comparative } \\
\text { Status }\end{array}$ & $\begin{array}{c}\text { Differences } \\
\text { between } \\
\text { averages }\end{array}$ & Significance \\
\hline \multirow[t]{2}{*}{ Integration } & $\begin{array}{l}\text { I don't have a } \\
\text { handicap in } \\
\text { my family }\end{array}$ & $\begin{array}{c}\text { I have a } \\
\text { disabled child } \\
\text { My family has } \\
\text { a disabled } \\
\text { child }\end{array}$ & $\begin{array}{l}0.56- \\
0.60\end{array}$ & $\begin{array}{c}* . \cdots \\
0.61\end{array}$ \\
\hline & $\begin{array}{c}\text { I have a } \\
\text { disabled child }\end{array}$ & $\begin{array}{c}\text { My family has } \\
\text { a disabled } \\
\text { child }\end{array}$ & 0.49- & $\because \cdots 6^{*}$ \\
\hline
\end{tabular}

The presence of statistically significant differences in favor of the case (I have a disabled child) when compared 
to the level (I do not have a disabled in my family) at the level of significance $(0.000$.

The presence of statistically significant differences in favor of the case (in the families of disabled children) when compared to the level (I have a disabled child) at the level of significance (0.006).

\section{5) The fifth hypothesis:}

There are no statistically significant difference in the attitude towards integration among the handicapped according to the type of disability

To validate that hypothesis, a single variance analysis test was used to determine The significance of differences in the responses of the study sample to the integration scale by the type of disability.

Table ( 9 ) Single variance analysis test

\begin{tabular}{|c|c|c|c|c|c|c|c|}
\hline the hub & $\begin{array}{c}\text { Contrast } \\
\text { Source }\end{array}$ & $\begin{array}{c}\text { Total } \\
\text { squares }\end{array}$ & $\begin{array}{c}\text { Degrees } \\
\text { of } \\
\text { freedom }\end{array}$ & $\begin{array}{c}\text { Average } \\
\text { of } \\
\text { squares }\end{array}$ & $\begin{array}{c}\text { The } \\
\text { value } \\
\text { of } p\end{array}$ & $\begin{array}{c}\text { Significance } \\
\text { level }\end{array}$ & Significance \\
\hline \multirow{3}{*}{ Integration } & $\begin{array}{r}\text { Between } \\
\text { groups }\end{array}$ & 58.773 & 6 & 9.796 & \multirow{3}{*}{44.000} & \multirow{3}{*}{$\cdots \cdot$} & \multirow{3}{*}{ Function } \\
\hline & $\begin{array}{l}\text { Within } \\
\text { groups }\end{array}$ & 42.967 & 193 & \multirow{2}{*}{223.} & & & \\
\hline & Total & 101.740 & 199 & & & & \\
\hline
\end{tabular}

$D$ at the significance level $(\mathbf{0 . 0 5})$

From the previous table, it is clear that there are statistically significant differences in the attitude towards integration among the handicapped according to the type of disability.

To determine the direction of the differences, the LSD test was performed 
Table ( 10 ) the LSD test

\begin{tabular}{|c|c|c|c|c|}
\hline The HUP & $\begin{array}{l}\text { Type of } \\
\text { Disability }\end{array}$ & $\begin{array}{l}\text { Comparative } \\
\text { Nu Disability }\end{array}$ & $\begin{array}{l}\text { Differences } \\
\text { between } \\
\text { averages }\end{array}$ & Significance \\
\hline \multirow[t]{6}{*}{ Integration } & $\begin{array}{l}\text { Impaired } \\
\text { mobility }\end{array}$ & $\begin{array}{l}\text { Retardation } \\
\text { Visual } \\
\text { impairment } \\
\text { Speech } \\
\text { disorders } \\
\text { Impaired } \\
\text { hearing } \\
\text { Autism } \\
\text { learning } \\
\text { difficulties }\end{array}$ & $\begin{array}{l}1.08- \\
0.24 \\
0.38- \\
0.34- \\
0.03- \\
1.03-\end{array}$ & $\begin{array}{l}0.000 * \\
0.079 \\
0.00 * \\
0.311 \\
\text { 0.778 } \\
\text { 0.00* }\end{array}$ \\
\hline & Retardation & $\begin{array}{l}\text { Visual } \\
\text { impairment } \\
\text { Speech } \\
\text { disorders } \\
\text { Impaired } \\
\text { hearing } \\
\text { Autism } \\
\text { learning } \\
\text { difficulties }\end{array}$ & $\begin{array}{l}0.84- \\
1.47- \\
1.43- \\
\\
1.11- \\
0.055-\end{array}$ & $\begin{array}{l}* . . \cdots \\
* \cdot . \cdots \\
* \cdot . \cdots \\
* . . \cdots \\
\cdot .704\end{array}$ \\
\hline & $\begin{array}{l}\text { Visual } \\
\text { impairment }\end{array}$ & $\begin{array}{l}\text { Speech } \\
\text { disorders } \\
\text { Impaired } \\
\text { hearing } \\
\text { Autism } \\
\text { learning } \\
\text { difficulties }\end{array}$ & $\begin{array}{l}0.62- \\
0.58- \\
0.27- \\
0.79-\end{array}$ & $\begin{array}{l}* 0.000 \\
0.100 \\
\mathbf{0 . 1 1 3} \\
* 0.000\end{array}$ \\
\hline & $\begin{array}{l}\text { Speech } \\
\text { disorders }\end{array}$ & $\begin{array}{l}\text { Impaired } \\
\text { hearing } \\
\text { Autism } \\
\text { learning } \\
\text { difficulties }\end{array}$ & $\begin{array}{l}0.04 \\
0.34- \\
1.41- \\
\end{array}$ & $\begin{array}{l}\mathbf{0 . 9 0 3} \\
* 0.013 \\
* 0.000\end{array}$ \\
\hline & $\begin{array}{l}\text { Impaired } \\
\text { hearing }\end{array}$ & $\begin{array}{l}\text { Autism } \\
\text { learning } \\
\text { difficulties }\end{array}$ & $\begin{array}{l}0.037 \\
1.37-\end{array}$ & $\begin{array}{l}0.390 \\
* 0.000\end{array}$ \\
\hline & Autism & $\begin{array}{l}\text { learning } \\
\text { difficulties }\end{array}$ & 1.07- & $* 0.000$ \\
\hline
\end{tabular}


- There are statistically significant differences in favor of (mental retardation) and (speech disorders) and (learning difficulties) when compared (motor disability) at the level of significance (0.000).

- There are statistically significant differences in favor of (visual disability), (speech disorders), (hearing disability) and (autism) when compared (mental retardation) at the level of significance (0.000).

- There are statistically significant differences in favor of (speech disorders) and (learning difficulties) when compared (visual impairment) at the level of significance (0.000).

- There are statistically significant differences in favor of (autism) and (learning difficulties) when compared (speech disorders) at the level of significance (0.013) and (0.000), respectively

- There are statistically significant differences in favor of (learning difficulties) when compared (hearing impairment) at the level of significance (0.000).

\section{Study Recommendations :}

From the above we can present a number of recommendations that can be summarized as follows :

- Establishing more integration schools in different cities and villages in El Menoufia governorate due to the proven effect of the effective integration process of people with disabilities with ordinary people - as indicated by previous studies - and its impact on their personal, social and skill compatibility.

- Design a number of training courses for teachers and staff in schools of the disabled, and parents of children with disabilities, as well as normal students 
to be aware of how to deal in a natural way with the disabled

- Working on the design and application of integration research on a large scale and in the different Egyptian governorates.

- Directing the media to the need to focus in various media programs on the importance and usefulness of the integration system and awareness of its advantages and positive effects.

\section{References :}

- Adegboyega, Lateef Omotosho (2019) Challenges and Adjustment Needs Of Students With Special Needs In Ilorin Metropolis, Kwara State. IFE PsychologIA . 27 (1) , 61-74., Database: Academic Search Ultimate.

- Aksoy, Ayse B.; Yildirim, Gonca, B. ( 2008 ) . A Study of the Relationships and Acknowledgement of Non-Disabled Children with Disabled Siblings . Educational Sciences: Theory and Practice, 8 (3), 769-779.

- Al-Abdul Gabbar, Abdul Aziz (1998) Symposium entitled Integration of Persons with Special Needs in GCC Countries, Bahrain 2: 4 March 1998.

- Abdul Hamid, Mohamed Ibrahim (2003): Integrating mentally retarded children with normal children in some activities and developing their personal and social compatibility, Journal of Psychology, Jan (65), 118- 139.

- Al- Abdul-Jabbar, Abdul Aziz bin Mohammed \& Massoud, Wael Mohammed (2002). Survey of Principals and Teachers opinions in Normal Schools on integration Programs . Educational Research Center, College of Education, King Saud University, Areyad :Kingdom of Saudi Arabia. Deanship of Scientific Research ( 180 ), 1- 61.

- Al-Khashrami, Sahar Ahmad (2011) Evaluation of Support Services for Students with Special Needs, King Saud University 
Journal: Educational Sciences and Islamic Studies, 23 (1) , 99-134 .Al-Khatib, Jamal and Al-Hadidi, Mona (2014) Introduction to Special Education. Fifth Edition. Amman : Dar Al Fikr .

- Al-Qaryouti, Ibrahim \& Abbas, Mahmoud El-Sayed (2009). Attitudes of Principals and Teachers towards Educational Integration of Special Needs in General Education Schools in Oman. Journal of Educational and Psychological Studies, Sultan Qaboos University, 3( 1), 24- 46 .(

- Al Rousan, Farouk ( 2001). Psychology of Special Needs Children - Introduction to Special Education. Amman, Dar Al Fikr.

- Al Sartawi, Zeidan Ahmad (1995), Attitudes of Teachers and Students Towards Integrating Children with Disabilities in Regular Classes, Contemporary Education journal, 38 ( 4 ), 183 219.

- Al Sartawi, Zidane \& Alshakhes, Abdul Aziz \& Al Jabbar, Abdul Aziz. (2000): Comprehensive Integration of People With Special Needs (Concept and Theoretical Background). Al Ain: Dar Elketab Algameey.

- Al Sayegh, Amal Mustafa El Minshawi (2011): A comparative Study Of The Attitude of University Students and Teachers Of Special Education Towards the Integration and Employment of The Disabled. Psychological Studies journal , 21( 3 ), 423- 446.

- Alshakhes , Abdul Aziz Al-Sayed. (1986) A Study of the Attitudes of Some Workers in the Field of Education towards the Disabled, Educational Studies journal , 1(4) , 63-107.

- Cansiz, Mustafa; Cansiz, Nurcan ( 2018 ). Sentiments, Attitudes, and Concerns about Inclusion: Early Years in Teacher Education Programs . Online Submission, Erzincan University Journal of Education Faculty . 20 (1) , 167-183 .

- Center, Y. \& Curry, C. ( 1993) . A Feasibility Study of A Full Interaction Model Develop for A Group Student Classified as Mildly Intellectually Disabled . International Journal of Disability Development and Education , 40 ( 93 ), 217 - 235. . 
- Chitiyo,Morgan; Hughes,ElizabethM.; Chitiyo,George; Changara, DarlingtonM.; Itimu-Phiri,Ambumulire; Haihambo,

Cynthy; Taukeni, Simon G.; Dzenga, Chaidamoyo G. (2019). Exploring teachers' special and inclusive education professional development needs in Malawi, Namibia, and Zimbabwe. International Journal of Whole Schooling, 15(1) , 28 - 49.

- Courduff, Jennifer(2011)One Size Never Fits All:Tech Integration for Special Needs. Learning \& Leading with Technology, 38 (8) , 16-19.

- Dheeb, Raed Al-Sheikh, and Muhaidat, Mohammed (2013). Skills for students with autism to integrate them in regular schools from the point of view of teachers. Educational Sciences Studies Journal , Jordan. 40 (4) , 1288-1305 .

- Dupoux, Errol ; Wolman, Clara \& Estrada, Elisa . ( 2005 ) Teachers Attitude Toward Integration of Students With Disabilities in Haiti And United States, International Journal of Disability , Development \& Education , 52 ( 1 ) , 43- 58 .

- Educational Psychological and Environmental Information Center, (2014). Attitudes of Primary and Middle School Teachers and Administrators about the Integration of Students with Special Needs in Regular Schools in Kingdom of Saudi Arabia . Special Education Journal. (9),155 . Al Manhal Collections.

- Ehrenberg, Harry L. ( 2019) . Special Needs Estate PlanningSeven Overlooked Challenges. Journal of Financial Service Professionals, Vol. 73 ( 5 ) , 56-63.

- El Desoki, Walaa Labib Mohamed (2010). Dimensions of the Argument Behavior ( a Comparative Study Between The Blind and Sighted People ), Unpublished Doctoral Thesis, University of Menoufia: Faculty of Arts, Egypt.

- Esentas, Melike; Guzel, Pinar; Vural, Mehmet ( 2019 ) . Employment of the First Graduates of the Department of Exercise and Sport Education in the Disabilities: A Qualitative Research. Journal of Education and Training Studies, 7 ( 3 ), 161-166 . 
- Fouad, Eman \& Ibrahim, Hisham.( 2007). Developing social skills for children with special needs. Cairo: Dar Elketab Alhadeath.

- Freeman, Stephanny F. N.; Alkin, Marvin C. (2000) . Academic and Social Attainments of Children With Mental Retardation in General Education and Special Education Settings, Texas , Remedial and Special Education , 21(1), 3- 18 .

- Hakim, Abdul Hamid bin Abdul Majeed (2009). Attitudes of Teachers of Elementary and Intermediate Schools in Makkah towards Integration Policy in Public Schools: A Comparative Study. Journal of the Faculty of Education, Banha University, Egypt 35(3) , $191-214$.

- Hardiman, S.; Fitzsimons, E.; Guerin, S.(2008 ) .Acomparison of the Social Competense of Children With Moderate Intellectual Disability in Inclusive Versus Segregated School Settings : Research in Developmental Disabilities , A Multidisciplinary Journal , Florida , 30 (2) , 397- 407.

- Hegazy, Nadia Abdul Aziz Mohamed (2012) Evaluation programs of work with groups in the development of social integration skills for children with autism: an study on the autism centers in Fayoum Governorate. Journal of Studies in Social Work and Humanities. Egypt 33 (10) , 40- 65 .

- Ibrahim, Ibrahim Abdel Rahman 2008, Disabled Child (Its provisions and legitimate rights the legal protection of people with special needs), the scientific journal - Al-Zaeem Al-Azhari University, Sudan ( 5 ), 51- 68.

- Kaffemanien, Irena \& Kaffemanas , Romanas ( 2007 ). The Attitude to the Integration of the Visually Impaired, Department of Special Education Studies, Siauliai University .

- Karal, Hasan; Cebi, Ayca; Turgut, Yigit Emrah( 2011 ) . Synchronic Distance Education from the Perspective of a Handicapped Person . Turkish Online Journal of Distance Education, 12 ( 2 ), 183-192. 
- Kashif, Eman ( 1999) : The Effectiveness of A Program of School Activities in the Integration of Children with Disabilities (Mentally - Acoustically) with Ordinary Children, The Sixth Psychological Counseling Conference, Ain Shams University, Cairo 10 : 12 November 1- 42.

- Konovalova, Natalia ( 2016 ) . Personal Integration Resources of Mentally Handicapped Teenagers into Society Bulgarian Comparative Education Society, Paper presented at the Annual International Partner Conference (4th, Sofia, Bulgaria, Jun 14-17, 2016), (116-119) .

- Omaira, Salah (2001) Educational Integration of The Mentally handicapped between support and opposition, the second meeting of the Gulf Disability Society from 9: 11 February .

- Rodriguez, Claudia Castillo; Garro-Gil, Nuria.( 2015 ). Inclusion and Integration on Special Education . In The Proceedings of 6th World Conference on educational Sciences, Procedia - Social and Behavioral Sciences. 2 June 2015( 191 ) , 1323-1327 Database: ScienceDirect.

- Selema , Fatema Mohamed Abdel Fattah( 2017 ). " The Effect of The Method of Integration Between Students with Mental Disabilities and The Good Who Are Accustomed to Harmonic Behavior And Learning Some Basic Skills in Table Tennis . International Journal of Sports Science \& Arts - English . 3 ( 2 ), 89-108.

- Shash, Sohair (2001): The Effectiveness of a Program for Developing Some Social Skills in Inclusion and Isolation Systems and its Effect on Reducing Behavioral Disorders in Mentally Retarded Children . Unpublished doctoral thesis, Faculty of Education, Zagazig University .

- Dixon,Sheryle.(2005 Inclusion Not Segregation or Integration Is Wherea Student with Special Needs Belongs. The Journal of Educational Thought. 39(1), 33-53.

- Tavarez DaCosta, Pedro.( 2019 ) . EFL Programs for People with Special Needs in Different National Settings Online 
Submission.74pp.(ED592751) FULL TEXT FROM ERIC, Database: ERIC.

- Kellett,Mary(2007)Commonsense Methods for Children with Spe cial EducationalNeeds ( 5 th Edition) Peter Westwood . British Journal of Educational Studies. 55(4) , 478-480

- Rafferty ,Yvonne ; Piscitelli, Vincenza ; Boettcher , Caroline (2003) The Impact of Inclusion on Language Development and Social Competence among Preschoolers with Disabilities. Council for exceptional children. 69 ( 4 ), 467 - 479 .

- Ziadat, Ayed H.; Atiyat, Fatima A.( 2018 ). The Attitudes of the Holy Land Institute for the Deaf-Salt, Jordan towards Deaf Socially and Educationally. Journal of Education and Learning, 7 (1) , 142-153 . 